\title{
Comparison of Refractive Measures of Term and Preterm Children Aged One Year Old
}

\author{
Ayşin Tuba Kaplan, ${ }^{1}$ (1) Leyla Yavuz Sarıçay, ${ }^{2}$ \\ (1) Ayşe Yeşim Oral Aydın, ${ }^{1}$ (1) Şaban Şimşek
}

\author{
'Department of Opthalmology \\ Dr. Lütfi Kırdar Kartal Training and \\ Research Hospital, \\ İstanbul, Turkey \\ 2Department of Opthalmology \\ Kanuni Sultan Süleyman Training \\ and Research Hospital, \\ Istanbul, Turkey \\ Submitted: 21.10.2019 \\ Accepted: 22.01 .2020 \\ Correspondence: \\ Ayşin Tuba Kaplan, \\ Dr. Lütfi Kırdar Kartal Eğitim ve \\ Araştırma Hastanesi, \\ Göz Hastalıkları Kliniği \\ İstanbul, Turkey \\ E-mail: aysintuba@icloud.com
}

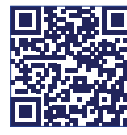

Keywords: Hyperopia; myopia; preterm children; retinopathy of prematurity.

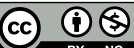

This work is licensed under a Creative Commons The

\begin{abstract}
Objective: To compare the refractive measures of preterm and full-term children aged I year old.

Methods: Fifty two eyes of 26 preterm children and 44 eyes of 22 term children were included in this study. Group I consisted of full-term subjects (mean GA 38.7 weeks), group 2 consisted of (mean GA 31.6 weeks) preterm subjects with no retinopathy of prematurity (ROP) and group 3 was included preterm subjects (mean GA 27.8 weeks) affected by ROP which required no treatment. All patients had undergone control examinations of autorefraction by Plusoptix S08 (PX) without cycloplegia and than fundoscopic evaluation at first year. The obtained refraction values were recorded as spherical equivalent (SE). The mean SE between the groups was compared statistically.
\end{abstract}

Results: Mean SE of group I was statistically significant compared to group 2 and $3(p<0.0$ I), difference in SE between group 2 and 3 was weaker but also significant $(p<0.05)$. The rate of myopia in ROP (+) group 3 (45\%) was higher than group I (16\%) and group $2(38 \%)$ and the rate of hyperopia in group I (52\%) was quite higher than group $2(\% \mid 3)$ and group $3(\% \mid 0)$. The percentage of astigmatism were significantly higher in group $2(85 \%)$ and $3(53 \%)$ than group I (25\%).

Conclusion: Refractive errors are more often in preterm infants even in the absence of ROP. Therefore screening for refractive errors in preterm children is important to prevent amblyopia.

\section{INTRODUCTION}

With the development of neonatal care and treatment options, the survival chance of premature births and low birth weight babies has also increased. However, it is more frequently encountered with many ophthalmological problems such as retinopathy of prematurity. ${ }^{[1]}$ Studies have shown that the frequency of myopia, astigmatism, anisometropia, strabismus and amblyopia in children born preterm is higher than term children. ${ }^{[2-4]}$ Again, the prevalence of myopia in preterm children is higher when compared with term children, whether PR is developed or not. Some studies argue that there is a negative correlation between the incidence of myopia and gestational age and low birth severity, and a positive correlation with the severity of PR. ${ }^{[3]}$ Although the mechanism of myopia development in preterm children is not yet clear, various studies have suggested that myopia may be related to increased corneal astigmatism, decreased anterior chamber depth, and in- creased lens refractive power, or it may have developed due to structural changes caused by laser therapy. ${ }^{[1,5,6]}$

In our study, we aimed to compare the refraction values of both term children of the same age and patients with and without retinopathy among themselves, and the refraction values of children over I year of ages who were followed up in our screening program due to preterm birth.

\section{MATERIALS AND METHODS}

We followed up 52 eyes of 26 babies in our clinic within the framework of our screening program due to preterm birth and 44 eyes of 22 term babies who came for routine I year of age control were evaluated retrospectively with the approval of the ethics committee. The patients are consisted of cases referred to us from our own hospital or external centers. The study was conducted in accordance with the principles of the Declaration of Helsinki. 
Birth weeks, fundus examinations, PR stages, if any, and I-year-old refraction values of all premature patients were recorded. Patients with no retinopathy (PR -) and patients with stage I, stage 2 retinopathy $(P R+)$ in various zones that did not require treatment or immature retinal vascular development (vascular maturation not yet completed) were included in the study.

Refraction values of all patients at I year were measured with automatic infrared videoretinoscopy (PlusoptiX S08) device without cycloplegia. Refraction was measured with cycloplegine retinoscopy for those who could not be measured with the device. These cases were not included in the study.

Refraction error difference of 1.0 diopter (D) and above between the two eyes was evaluated as anisometropia, values other than $-1.0 \mathrm{D}$ and +2.0 D were accepted as ametropia, and cylindrical values of I diopter and above were accepted as astigmatism.

SPSS 15.0 software Windows' (Statistical Package for the Social Sciences, Chicago, IL, USA) statistical package program was used in the analysis of the data. Paired t-test was used to compare variables.

\section{Symptoms}

The gestational average age of term infants (Group I, n=44 eyes) included in the study was $38.7 \pm 0.9$ weeks, the gestational average age of preterm infants without retinopathy (Group 2, $\mathrm{n}=32$ eyes) was $31.6 \pm 2.03$ weeks, and gestational average age of preterm cases with retinopathy (Group 3, $\mathrm{n}=20$ eyes) was $27.8 \pm 1.01$ weeks. 14 boys, 8 girls were twenty-two term babies, I 5 boys, II girls were preterm babies. When fundus examinations of 20 eyes that make up Group 3, have PR but do not require treatment, are evaluated; Stage I in various zones in 8, Stage 2 PR was detected in 3 of them, while the vessels in Zone 3 were immature in 9 cases.

The average SE of group I was determined as $+0.96 \pm 1.29$, group 2 was determined as $-0.18 \pm 1.13$ and group 3 was determined as $-1.22 \pm 1.93$. When the average SE of group I was compared with group 2 and group 3, the difference was found to be statistically highly significant $(p<0.01)$. When we look at the difference in SE values of group 2 and group 3 , it was again statistically significant, although the difference was not very high $(p<0.05)$.

Myopia in 7 cases (16\%) in group I, hyperopia in 23 cases (52\%), myopia in 12 cases (38\%) in group 2 , hyperopia in 4 cases (13\%) and myopia in 9 cases in group 3 (\%). 45), hyperopia (10\%) in 2 cases were detected. While the myopia rate in group 3 with PR (+) was higher than group I and group 2, the rate of hyperopia in group I was found to be significantly higher than group 2 and group 3 (Table I).

The average of astigmatism values of group I was determined as $-0.49 \pm 0.75$, group 2 was determined as $-0.95 \pm 1.20$ and group 3 was determined as $-2.24 \pm 0.67$. When we compare the average values of astigmatism between the groups, the difference between group I and group 2 is statistically sig- nificant $(p<0.05)$, while the difference between group I and group 3 is highly significant $(p<0.01)$. The difference was also significant $(p<0.0 \mathrm{l})$ between group 2 and 3 . The rate of patients with astigmatism was significantly higher in group 3 (85\%) and group 2 (53\%) with premature births compared to group I (25\%) with term babies (Table 2 ).

\section{RESULTS}

Children born preterm are faced with a higher rate of refractive defects than term babies. Especially myopia and astigmatism values are determined higher than term cases. For this reason, all children born preterm should be followed up regularly in terms of refractive defects and amblyopia that may develop as a result. We think that high measurements other than normal refraction values obtained with the devices used for screening should be confirmed by retinoscopy measurements with cycloplegia. However, the presence of high refractive defects in preterm cases without PR indicates that emmetropization is affected by gestational age and birth weight without the development of retinopathy. Studies with larger series are needed to show this relationship more clearly.

\section{DISCUSSION}

High refractive errors are a common finding in both preterm and term newborns which we attain frequently. High hyperopia and astigmatism seen in term babies tend to decrease rapidly in the first year of life, this is called emmetropization. ${ }^{[7]}$ Many studies report that myopic refractive error is quite high in preterm births, and it is determined that the frequency of anisometropia and astig-

Table I. Myopic and hyperopia distributions of the groups

n

Group I

Myopic 7 16

Hyperopia 23

Group 2

Myopic 38

Hyperopia

12

13

Group 3

Myopic 45

Hyperopia 9 10

Table 2. Astigmatism distributions of the groups

\begin{tabular}{lc}
\hline Percentage of astigmatism groups & $\%$ \\
\hline Group I & 25 \\
Group 2 & 53 \\
Group 3 & 85
\end{tabular}


matism is higher in this group than term babies. ${ }^{[8-11]}$

It has been shown that the prevalence of myopia in preterm infants increases with the degree of prematurity and the severity of PR. ${ }^{[10,1]]}$ Some authors have described three types of myopia associated with premature. The first is physiological myopia due to premature birth and gestational stage, the second is myopia due to disruption in the development of the anterior segment, regardless of the development of PR, characterized by narrow anterior chamber angle, increased corneal curvature and spherical lens, and the third type is myopia that can range from mild to severe due to severe PR. ${ }^{[12]}$ Studies have reported that although PR is not present in preterm cases, emmetropization is affected depending on gestational age and birth weight. In preterm cases, it was observed that as the gestational week decreased, myopic values increased and SE values decreased considerably. ${ }^{\left[{ }^{\prime \prime}\right]}$ In our study, we found that the SE values of preterm cases in group 3 , whose average gestational week was less than 28 weeks, were more myopic than the other groups. In our study, when the SE values of the groups were compared, we found that there was a statistically high difference between term cases and preterm cases $(p<0.0 I)$. Also, SE values of the group without retinopathy among preterm cases were found to be statistically significantly higher than the group with retinopathy $(p<0.05)$. When we look at the literature, the difference in high SE values between term cases and preterm cases is different from the results in the literature. ${ }^{[1,8,13]}$ In the study conducted by Özdemir et al., ${ }^{[1]}$ no significant difference was found between the SE values of the preterm group without PR and the group who had PR but regressed without treatment in the first year. However, in our study, the average gestational age of the PR group that regressed without treatment $(27.8 \pm \mathrm{I} .0 \mathrm{I})$ was lower than the study of Özdemir et al., ${ }^{[I]}$ the decrease in SE values as the gestational age decreases may explain the increase in SE difference between the two groups, and at the same time, our measurements were screened without cycloplegia. The fact that it was made with the device may also have caused the difference.

In some fulfilled studies, it has been reported that refractive disorders in preterm babies who did not have PR in the preschool period and who did not need PR treatment were similar. ${ }^{[14-16]}$ It was also reported that these children reached the refraction values of term cases in the preschool period. On the contrary, in some studies, it was reported that the high refraction values in the pre-school group without PR and in the preterm group who did not require $P R$ treatment are continued. ${ }^{[17-19]}$ In our cases, whether the high refraction values and the difference between the groups will continue or not, can be determined with longer follow-ups.

In the cryotherapy for retinopathy of prematurity (CRYOROP) and The early treatment for retinopathy of prematurity (ETROP) studies, it was observed that myopia or astigmatism are increased up to 6-9 months in threshold PR groups where they followed refractive disorders from
3 months to age of 3 or 5.5 years and that it is stabile after the age of $1 .{ }^{[3]}$ Larsson and Saunders reported in their study that myopic shift was seen in early infancy in cases without PR or with mild PR, that decrease around the $6^{\text {th }}$ month and catch term cases around the age of 2 years. ${ }^{[20,21]}$ In our study, we found the rate of myopia as $16 \%$ in term cases, $36 \%$ in the preterm group without retinopathy and $45 \%$ in the group with retinopathy. Davitt et al. ${ }^{[16,22]}$ reported the incidence of myopia as $64.5 \%$ in their preterm study under $1250 \mathrm{gr}$ and Quin et al. reported this as $58 \%$. In these studies, attention was drawn to birth weight particularly and it was emphasized that low birth weight was an important risk factor for myopia. In the study conducted by Zhu et al., ${ }^{[I]}$ they reported the incidence of myopia as $2.22 \%, 6.73 \%$ and $14.29 \%$, respectively, in similar groups. In this study, they attributed the low myopia rates to the higher birth weight of the preterms in their study. In order to determine whether the high myopia rates in our study are related to low birth weights, it will be appropriate to consider birth weights in future studies.

In our study, we observed the rate of hyperopia as $52 \%$ in term cases, and determined $13 \%$ and $10 \%$ in preterm cases with and without retinopathy, respectively. In the study where Muna et al. classified preterm cases as no PR, mild PR but not requiring treatment and requiring treatment, in their first age measurements, 3D and below hyperopia values were reported as $39.2 \%, 28.6 \%$ and $22 \%$, respectively, while Akdoğan et al. ${ }^{[5]}$ reported that 2D and higher hypermetropia was $56.3 \%$ in preterms born below 36 weeks. [12] According to the studies conducted, it is showed that hyperopia values decreased in the preschool period. In the study conducted by Özdemir et al., ${ }^{[1]}$ the incidence of hyperopia in premature children aged 5-7 years without ROP was reported as $21 \%$. In another study conducted by Küçükevcilioğlu et al. ${ }^{[24]}$ in which preschool children were included, the incidence of hyperopia was indicated as $28.8 \%$ in children with moderate PR and $22.3 \%$ in children without RP. In our study where we accepted hyperopia above $2 \mathrm{D}$, we indicated the rate of hypermetropia as $52 \%$ in cases who were born term at I age, and we indicated the cases with retinopathy and without preterm as 13\% and $10 \%$, respectively. The difference in hyperopia rates especially in preterm babies in our study with other studies may be related to the differences in the gestational weeks of the babies included in the study.

Saunders et al., ${ }^{[20]}$ reported that gestational age had a great role in high astigmatism values in their study fulfilled with 59 preterm infants. They determined that higher astigmatism values were detected at birth in very preterm babies and gestational age was decreased in after life. In our study, higher astigmatism values were determined in the first year, especially in our preterm cases compared to term cases $(p<0.05)$, and significantly higher astigmatism values were recorded statistically between both preterm case group in the group with a lower gestational age $(p<0.01)$. In their study, According to fulfilled study, Muna et al. ${ }^{[2]}$ reported I-age astigmatism values as $54 \%$ and 
$53 \%$, respectively, in preterm cases without PR and mild PR findings. ${ }^{[12]}$ We found that our I-age astigmatism values $(53 \% / 85 \%$, respectively) were quite high in the groups with and without PR when compared to the results of the study, but this difference may have created as the cycloplegia refraction values were not obtained in our study and as the average gestational age was higher $(30.2 \pm 3.4 / 29.4 \pm 3.1)$ in the study of Muna et al. ${ }^{[12]}$

In our study, refractive values in the I.age were measured by automatic infrared videoretinoscopy (PlusoptiX S08) without cycloplegia. In a previous study conducted by Oral et al., ${ }^{[25]}$ this method was preferred because there are not any statistically significant difference between the results of the average spherical values videoretinoscopy without cycloplegia and retinoscopy with cycloplegia, and preferred because of ease of use in that age group. In spite of this, according to this study conducted on children between the ages of $6-14$, it was reported that the average cylindrical values obtained with PlusoptiX S08 without cycloplegia were statistically lower than the results of retinoscopy with cycloplegia significantly. In our study, we believe that measurements with and without cycloplegia should be compared in new studies in this age group, since both SE and astigmatism values were measured higher than other studies. At the same time, there are studies reporting that astigmatism values also change in preterm infants depending on the birth weight. ${ }^{[18,20]}$ Therefore, it would be appropriate to include the birth weights of the cases in future studies.

Ethics Committee Approval

Approved by the local ethics committee ( I // I/20 I4 date and number $89513307 / 1009 / 353)$.

Informed Consent

Retrospective study.

Peer-review

Internally peer-reviewed.

Authorship Contributions

Concept: A.T.K., L.Y.S., A.Y.A.; Design: A.T.K., A.Y.O., L.Y.S., Ş.Ş.; Supervision: A.T.K., A.Y.O.; Fundings: A.Y.O., A.T.K., L.Y.S., Ş.Ş.; Materials: A.T.K., A.Y.O., L.Y.S.; Data: A.Y.O., A.T.K., Ş.Ş.; Analysis: A.T.K., A.Y.O., L.Y.S., Ş.Ş.; Literature search: A.T.K., A.Y.O.; Writing: A.T.K., A.Y.O.; Critical revision: A.T.K., A.Y.O., Ş.Ş.

Conflict of Interest

The authors declare that there is no conflict of interest.

\section{REFERENCES}

1. Zhu X, Zhao R, Wang Y, Ouyang L, Yang J, Li Y, et al. Refractive state and optical compositions of preterm children with and without retinopathy of prematurity in the first 6 years of life. Medicine (Baltimore) 2017;96:e8565.[CrossRef]

2. Haines L, Fielder AR, Scrivener R, Wilkinson AR; Royal College of Paediatrics and Child Health, the Royal College of Ophthalmologists and British Association of Perinatal Medicine. Retinopathy of prematurity in the UK I: the organisation of services for screening and treatment. Eye (Lond) 2002;16:33-8. [CrossRef]
3. Hsieh CJ, Liu JW, Huang JS, Lin KC. Refractive outcome of premature infants with or without retinopathy of prematurity at 2 years of age: a prospective controlled cohort study. Kaohsiung J Med Sci 2012;28:204-11. [CrossRef]

4. O'Connor AR, Stephenson T, Johnson A, Tobin MJ, Moseley MJ, Ratib S, et al. Long-term ophthalmic outcome of low birth weight children with and without retinopathy of prematurity. Pediatrics 2002;109:12-8. [CrossRef]

5. Akdoğan $\mathrm{M}$. The effect of premature retinopathy treatment modalities on refractive errors. Kocatepe Medical Journal 2019;20:33-9

6. Dhawan A, Dogra M, Vinekar A, Gupta A, Dutta S. Structural sequelae and refractive outcome after successful laser treatment for threshold retinopathy of prematurity. J Pediatr Ophthalmol Strabismus 2008;45:356-61. [CrossRef]

7. Saunders KJ. Early refractive development in humans. Surv Ophthalmol 1995;40(3):207-16. [CrossRef]

8. Kaya M, Berk AT, Yaman A. Long-term evaluation of refractive changes in eyes of preterm children: a 6-year follow-up study. Int Ophthalmol 2018;38:1681-8. [CrossRef]

9. Davitt BV, Dobson V, Quinn GE, Hardy RJ, Tung B, Good WV, et al. Astigmatism in the Early Treatment for Retinopathy Of Prematurity Study: findings to 3 years of age. Ophthalmology 2009;116:332-9.

10. Lok JYC, Yip WWK, Luk ASW, Chin JKY, Lau HHW, Young AL. Visual outcome and refractive status in first 3 years of age in preterm infants suffered from laser-treated Type 1 retinopathy of prematurity (ROP): a 6-year retrospective review in a tertiary centre in Hong Kong. Int Ophthalmol 2018;38:163-9. [CrossRef]

11. Ozdemir O, Tunay ZO, Acar DE, Acar U. Refractive errors and refractive development in premature infants. J Fr Ophtalmol 2015;38:934-40. [CrossRef]

12. Al Oum M, Donati S, Cerri L, Agosti M, Azzolini C. Ocular alignment and refraction in preterm children at 1 and 6 years old. Clin Ophthalmol 2014;8:1263-8. [CrossRef]

13. Holmström M, el Azazi M, Kugelberg U. Ophthalmological longterm follow up of preterm infants: a population based, prospective study of the refraction and its development. $\mathrm{Br} \mathrm{J}$ Ophthalmol 1998;82:1265-71. [CrossRef]

14. Quinn GE, Dobson V, Kivlin J, Kaufman LM, Repka MX, Reynolds JD, et al. Prevalence of myopia between 3 months and $51 / 2$ years in preterm infants with and without retinopathy of prematurity. Cryotherapy for Retinopathy of Prematurity Cooperative Group. Ophthalmology 1998;105:1292-300. [CrossRef]

15. Quinn GE, Dobson V, Davitt BV, Hardy RJ, Tung B, Pedroza C, et al. Progression of myopia and high myopia in the early treatment for retinopathy of prematurity study: findings to 3 years of age. Ophthalmology 2008;115:1058-64.e1. [CrossRef]

16. Davitt BV, Dobson V, Good WV, Hardy RJ, Quinn GE, Siatkowski $\mathrm{RM}$, et al. Prevalence of myopia at 9 months in infants with high-risk prethreshold retinopathy of prematurity. Ophthalmology 2005;112:1564-8. [CrossRef]

17. Fledelius HC. Pre-term delivery and subsequent ocular development. A 7-10 year follow-up of children screened 1982-84 for ROP. 3) Refraction. Myopia of prematurity. Acta Ophthalmol Scand 1996;74:297-300. [CrossRef]

18. Holmström G, Larsson E. Long-term follow-up of visual functions in prematurely born children-a prospective population-based study up to 10 years of age. J AAPOS 2008;12:157-62. [CrossRef]

19. Choi MY, Park IK, Yu YS. Long term refractive outcome in eyes of preterm infants with and without retinopathy of prematurity: comparison of keratometric value, axial length, anterior chamber depth, and lens thickness. Br J Ophthalmol 2000;84:138-43. [CrossRef]

20. Saunders KJ, McCulloch DL, Shepherd AJ, Wilkinson AG. 
Emmetropisation following preterm birth. Br J Ophthalmol 2002;86:1035-40. [CrossRef]

21. Larsson EK, Holmström GE. Development of astigmatism and anisometropia in preterm children during the first 10 years of life: a population-based study. Arch Ophthalmol 2006;124:1608-14. [CrossRef]

22. Quinn GE, Dobson V, Davitt BV, Wallace DK, Hardy RJ, Tung B, et al. Progression of myopia and high myopia in the Early Treatment for Retinopathy of Prematurity study: findings at 4 to 6 years of age. J AAPOS 2013;17:124-8. [CrossRef]
23. Özdemir M, Koylu S. Ocular growth and morbidity in preterm children without retinopathy of prematurity. Jpn J Ophthalmol. 2009;53:623-8. [CrossRef]

24. Küçükevcilioğlu M, Mutlu FM, Sarıcı SÜ. Ocular morbidities of premature children with mild or no retinopathy of prematurity. Turk J Pediatr 2015;57:129-35.

25. Oral Y, Gunaydin N, Ozgur O, Arsan AK, Oskan S. A comparison of different autorefractors with retinoscopy in children. J Pediatr Ophthalmol Strabismus 2012;49:370-7. [CrossRef]

\section{Term ve Preterm Çocukların Bir Yaş Refraksiyon Değerlerinin Karşılaştırılması}

Amaç: Preterm doğan çocukların I yaş refraksiyon değerlerinin term çocuklarla karşılaştırılması amaçlandı.

Gereç ve Yöntem: Çalışmaya 26 preterm çocuğun 52 gözü ile 22 term çocuğun 44 gözü dahil edildi. Term olan olgular [Gestasyonel yaş ortalaması (GY ort.) $=38.7 \pm 0.9$ hafta] grup I, preterm doğup retinopatisi olmayan olgular (GY ort. $=31.6 \pm 2.03$ hafta) grup 2 ve preterm doğan ve herhangi bir zonda evresi olan ama tedavi gerekmeyen olgular (GY ort. $=27.8 \pm 1.01$ hafta) ise grup 3 olarak değerlendirildi. Tüm olguların I yaş kontrol muayenelerinde, refraksiyon ölçümleri sikloplejisiz olarak Plusoptix S08 (PX) ile ölçüldükten sonra fundus muayeneleri yapıldı. Elde edilen refraksiyon değerleri sferik eşdeğer (SE) olarak kaydedildi. Gruplar arası SE ortalamaları istatistiksel olarak karşılaştırıldı.

Bulgular: Term doğan grup I'de ki bebeklerin SE ortalaması (+0.96 \pm 1.29$)$, grup $2(-0.18 \pm 1.13)$ ve grup $3(-1.22 \pm 1.93)$ ile karşılaştıııldığında istatistiksel olarak anlamlı derecede yüksek olduğu görüldü $(p<0.01)$. Grup 2 ve grup 3'ün SE ortalamaları arasındaki fark istatistiksel olarak karşılaştırıldığında ise düşük derecede olsa da anlamlı bulundu ( $p<0.05)$. PR (+) olan grup 3'ün miyopi oranı (\%45), grup I (\%।6) ve grup 2'ye (\%38) göre yüksek iken, grup I de hipermetropi oranı (\%52), grup 2 (\%13) ve grup 3’e (\%10) göre oldukça yüksek bulundu. Astigmatizması olan olguların oranı da grup 3 (\%85) ve grup 2'de (\%53) grup l'e (\%25) göre anlamlı şekilde yüksek idi.

Sonuç: Refraksiyon kusurları preterm doğan çocuklarda retinopati gelişmese bile term doğan bebeklere göre oldukça yüksek oranda görülmektedir. Bu nedenle preterm çocuklarda ambliyopi gelişimini engellemek için refraksiyon kusurları açısından tarama yapılması önem arzetmektedir.

Anahtar Sözcükler: Hipermetropi yöntemleri; miyopi; prematüre retinopati; preterm çocuklar. 